\title{
Dissemination and survival of non-indigenous bacterial genomes in pristine Antarctic environments
}

\author{
Lemese Ah Tow and Don A. Cowan
}

\begin{abstract}
Continental Antarctic is perceived as a largely pristine environment, although certain localized regions (e.g., parts of the Ross Dependency Dry Valleys) are relatively heavy impacted by human activities. The procedures imposed on Antarctic field parties for the handling and disposal of both solid and liquid wastes are designed to minimise eutrofication and contamination (particularly by human enteric bacteria). However, little consideration has been given to the significance, if any, of less obvious forms of microbial contamination resulting from periodic human activities in Antarctica. The predominant commensal microorganism on human skin, Staphylococcus epidermidis, could be detected by PCR, in Dry Valley mineral soils collected from heavily impacted areas, but could not be detected in Dry Valley mineral soils collected from low impact and pristine areas. Cell viability of this non-enteric human commensal is rapidly lost in Dry Valley mineral soil. However, S. epidermidis can persist for long periods in Dry Valley mineral soil as non-viable cells and/or naked DNA.
\end{abstract}

Keywords 16S rDNA PCR; Antarctica; Staphylococcus epidermidis; Microbial contamination

\section{Introduction}

The Dry Valleys of Eastern Antarctica harbor a variety of unique microbial biotopes, including lake systems, mineral soils, endolithic-bearing rock strata and seasonally inundated flush areas (WynnWilliams 1990; Cowan and Ah Tow 2004. Culturing and microscopic studies, comprehensively reviewed by Friedmann (1993), have shown that mineral soils contain a variety of bacteria, fungi, yeast and protozoa. Culture-independent techniques such as DNA fluorescent dyes (for example, SYBR Green) (Weinbauer et al. 1998; Carpenter et al. 2000) and ssu rRNA gene PCR techniques (Carpenter et al. 2000; Glockner et al. 2000; Gordon et al. 2000) have contributed significantly to the detection and identification of new microorganisms in these extreme environments, but so-called 'uncultured' phylotypes remain the dominant sequences isolated (Smith et al. unpublished results).

Various pathways for introducing microbes into Antarctica have been observed and these include atmospheric circulation (wind), oceanic currents, fish, migratory birds and marine mammals (Vincent 2000). While studies have shown that pollen and microorganisms are introduced into Antarctica via atmospheric circulation (Vincent 1988; Priscu et al. 1999), these can be considered as a means of natural dissemination. However, increases in human activities in Antarctica have accelerated the rate of introduction of nonindigenous microorganisms to the ice-free areas of the Antarctic continent. The durability or longevity of non-indigenous microorganisms in the Antarctic environment is also of concern. Numerous researchers have reported on the preservation of DNA in various environments, including amber (Cano and Borucki 1995), tundra soil (Stokstad 2003), permafrost (Willerslev et al. 2003) as well as in subfossil bones of Adelie penguins in Antarctica (Lambert et al. 2002). 
Scientific, exploratory and touristic interest in this unique continent has led to a rapid increase in human activities. Research activities in the Dry Valleys alone, serviced by only two scientific bases (McMurdo station (US) and Scott Base (NZ)), typically imposes 500-1,000 individuals across a reasonably localised area for durations of 2-8 weeks each austral summer period. The results of human activity potentially include physical disruption of surface soils, eutrofication of soils and water systems, and contamination by detritus, xenobi-otic chemicals and non-indigenous microorganisms.

Table 1 Eastern Antarctic Ross Island and Dry Valleys mineral soils sampling sites

\begin{tabular}{|c|c|c|c|}
\hline Site reference & Location & GPS reading & Designation $^{\mathrm{a}}$ \\
\hline CR1-2 & Cape Royds, $20 \mathrm{~m}$ from front of historic hut & $77^{\circ} 33.081^{\prime} \mathrm{S} 166^{\circ} 09.898^{\prime} \mathrm{E}$ & Medium impact area \\
\hline CE1-2 & $\begin{array}{l}\text { Cape Evans, } 20 \mathrm{~m} \text { from ground in vicinity of front door to historic } \\
\text { hut }\end{array}$ & $77^{\circ} 38.292^{\prime} \mathrm{S} 166^{\circ} 24.414^{\prime} \mathrm{E}$ & Medium impact area \\
\hline MAC1 & McMurdo station, from Derelict Junction bus stop & - & High impact area \\
\hline MAC2 & McMurdo station, from pedestrian entrance to coffee shop & - & High impact area \\
\hline SB1 & Scott Base, from vicinity of rear entrance to Base & - & High impact area \\
\hline SB2 & Scott Base, from vicinity of side entrance to stores hanger & - & High impact area \\
\hline $\mathrm{SB}(\mathrm{D})$ & Scott Base, floor dust from domestic vacuum cleaner & - & Positive control \\
\hline $\mathrm{BIC} 4$ & Bratina Island, pristine sample from ridge $\mathrm{S}$ of Salt Pond. & $78^{\circ} 03.991^{\prime} \mathrm{S} 165^{\circ} 32.753^{\prime} \mathrm{E}$ & Pristine site \\
\hline MVT12 & $\begin{array}{l}\text { Myers Valley, from steep ridge above frozen lake; Altitude, 2689' } \\
\text { asl. }\end{array}$ & $78^{\circ} 03.968 \mathrm{~S} 163^{\circ} 52.083 \mathrm{E}$ & Pristine site \\
\hline UWV1 & $\begin{array}{l}\text { Upper Wright Valley, pristine sample from elevated } \\
\text { valley. Altitude; } 4322^{\prime} \text { asl. }\end{array}$ & $77^{\circ} 30.674^{\prime} \mathrm{S} 160^{\circ} 40.164^{\prime} \mathrm{E}$ & Pristine site \\
\hline
\end{tabular}

\footnotetext{
${ }^{a}$ Impact status: Pristine site $<0.1 \mathrm{~h}$ human presence within $50 \mathrm{~m}$ radius of sample site p.a., Medium impact site $<200 \mathrm{~h}$ human presence within $50 \mathrm{~m}$ radius of sample site p.a., High impact site $>1,000 \mathrm{~h}$ human presence within $50 \mathrm{~m}$ radius of sample site p.a. Note that positive control sample $\mathrm{SB}$ (D) represents approximately $15,000 \mathrm{~h}$ total impact ( $24 \mathrm{~h}$ p.d.x 90 pax x $7 \mathrm{~d}$ accumulation)
} 

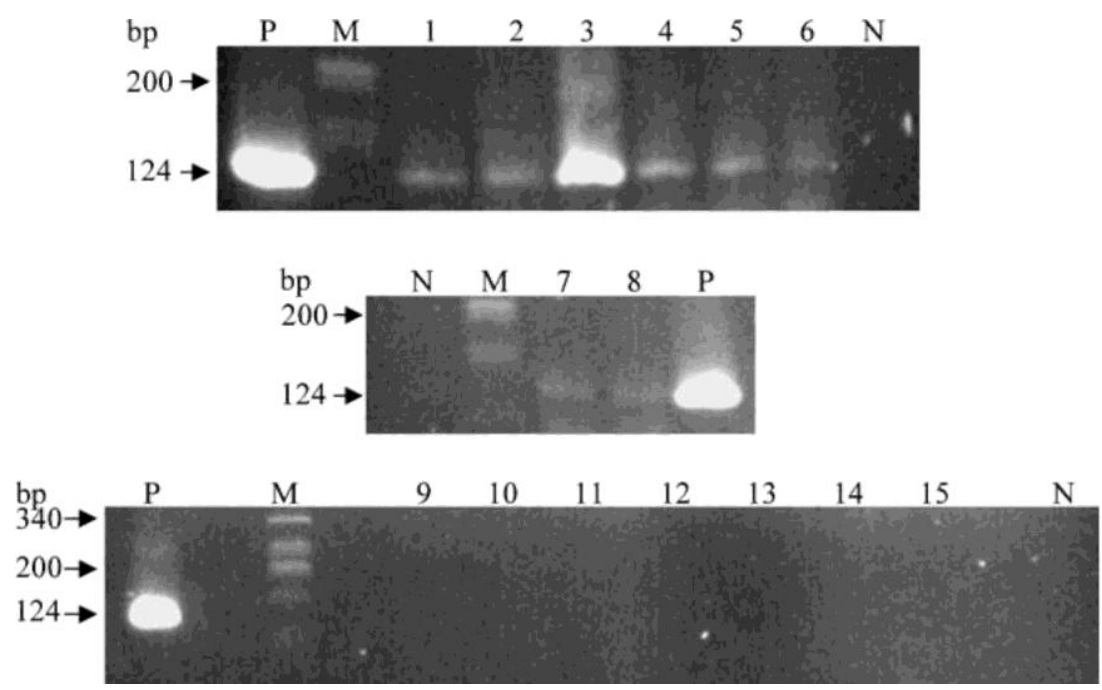

Fig. 1 Detection of Staphylococcus epidermidis in high impact, low impact and pristine sites in Antarctica. The S. epidermidis-specific PCR primers target a $124 \mathrm{bp} \mathrm{DNA} \mathrm{fragment} \mathrm{which} \mathrm{is} \mathrm{specific} \mathrm{to} \mathrm{the} \mathrm{S.} \mathrm{epidermidis} \mathrm{genome} \mathrm{(Martineau} \mathrm{et} \mathrm{al.} \mathrm{1996).} \mathrm{Approximately} \mathrm{10} \mathrm{ng} \mathrm{of} \mathrm{bulk} \mathrm{genomic} \mathrm{DNA,} \mathrm{extracted}$ from Antarctic Ross Dependency soil samples was used,as template DNA in S. epidermidis-specific PCR amplifications: SB1 (lane 1); SB2 (lane

2); SB(D) (lane 3); BIC1 (lane 4); BIC2 (lane 5); BIC3 (lane 6); MAC1 (lane 7); MAC2 (lane 8); CR1 (lane 9); CR2 (lane 10); CE1 (lane 11); CE2 (lane 12); BIC4 (lane 13); UWV1 (lane 14) and MVT12 (lane 15). N represents the PCR negative controls (sterile water as template); P represents the PCR positive controls (2 ng S. epidermidis genomic DNA as template); and M depicts the molecular weight marker (k Pst I). PCR products were visualized on a $2 \%$ agarose gel containing $500 \mathrm{ig} / \mathrm{ml}$ Ethidium Bromide

Microbial contamination has been detected at both the macroscopic (Eckford et al. 2002) and microscopic levels. For example, there are numerous reports on the isolation or detection of non-indigenous enteric bacteria derived from human faecal waste (McFeters et al. 1993; Edwards et al. 1998; Sjoling and Cowan 2000; Bruni et al. 1997; Baker et al. 2003). Here we show that non-enteric human commensal microbiota are rapidly disseminated into the Antarctic Dry Valley mineral soils tested, and that although cell viability is rapidly lost, non-viable cells and/or naked DNA persist for long periods. 

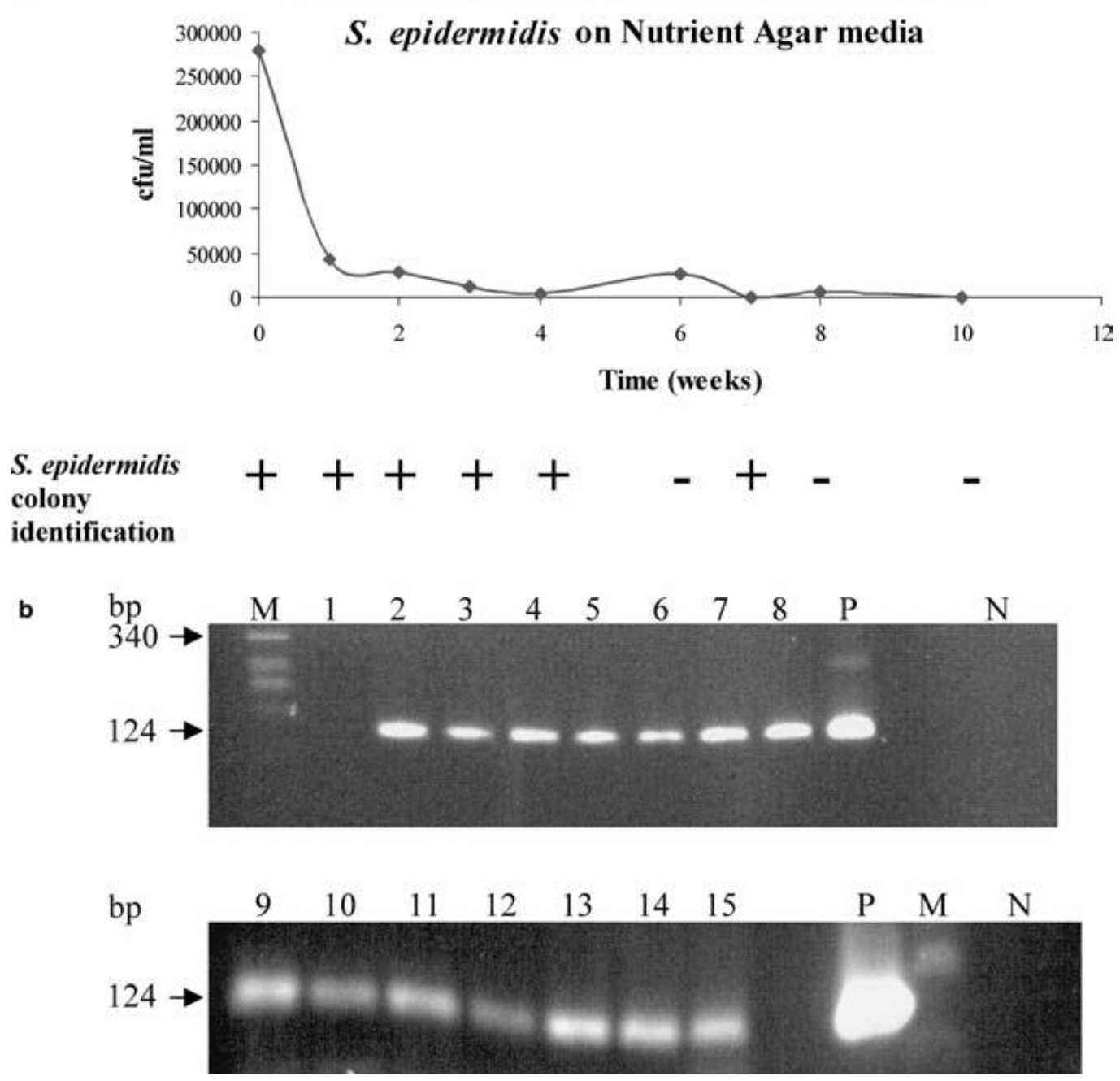

Fig. 2 S. epidermidis survival in BIC4 soil. a S. epidermidis isolation from BIC4 soil seeded with S. epidermidis. Plus signs represent isolation of S. epidermidis from the NA plates, while minus signs indicate failure to isolate $S$. epidermidis. b Detection of $S$. epidermidis in BIC4 soil seeded with $S$. epidermidis and incubated at $4^{\circ} \mathrm{C}$ for up to 54 weeks. DNA templates included total genomic DNA extracted from BIC4 soil (a pristine site) (lane 1); as well as BIC4 soil seeded with $1 \times 10^{5} \mathrm{cfu} / \mathrm{ml} S$. epidermidis and incubated at $4^{\circ} \mathrm{C}$ for various lengths of time. Time of extractions, from the seeded samples were as follows: time 0 (immediately after inoculation with S. epidermidis) (lane 2); 1 week (lane 3); 2 weeks (lane 4); 3 weeks (lane 5); 4 weeks (lane 6); 6 weeks (lane 7); 7 weeks (lane 8); 8 weeks (lane 9); 10 weeks (lane 10); 15 weeks (lane 11); 21 weeks (lane 12); 30 weeks (lane 13); 40 weeks (lane 14); and 54 weeks (lane 15). N represents the PCR negative controls (sterile water as template); P represents the PCR positive controls ( $2 \mathrm{ng}$ S. epidermidis genomic DNA as template); and $\mathrm{M}$ depicts the molecular weight marker (k Pst $\mathrm{I})$ 


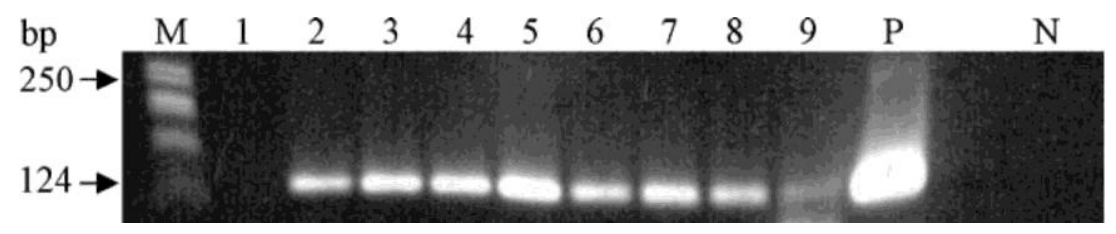

Fig. 3 Detection of S. epidermidis in BIC4 soil. Soil samples were seeded with S. epidermidis genomic DNA and incubated at $4{ }^{\circ} \mathrm{C}$ for up to 23.5 weeks. DNA templates included total genomic DNA extracted from BIC4 soil (pristine site) (lane 1); as well as BIC4 soil seeded with S. epidermidis genomic DNA equivalent to $1 \times 10^{5} \mathrm{cfu} / \mathrm{ml}$ and incubated at $4{ }^{\circ} \mathrm{C}$ for various lengths of time. Time of extractions, from the seeded samples, were as follows: time 0 (immediately after inoculation with S. epidermidis genomic DNA) (lane 2); 1.5 days (lane 3); 3.5 days (lane 4); 3 weeks (lane 5); 5.5 weeks (lane 6); 9.5 weeks (lane 7); 15.5 weeks (lane 8); and 23.5 weeks (lane 9). N represents the PCR negative control (sterile water as template); P represents the PCR positive control (2 ng S. epidermidis genomic DNA as template); and M depicts the molecular weight marker (k Pst I)

\section{Results and discussion}

Dry Valley mineral soils were collected aseptically in January 2002 from various sites in the Ross Dependency region, Eastern Antarctica, namely (i) pristine sites; (ii) low impacted areas such as historic huts; and (iii) heavily impacted areas (Table 1). Samples were kept frozen from the time of collection and stored at $-80^{\circ} \mathrm{C}$. Bulk DNA was extracted directly from the Antarctic Dry Valley mineral soils (Table 1) according to the modified Zhou method (Stach et al. 2001). Genomic DNA concentrations ranged between 0.098 ng/g w.w. soil. S. epidermidis, the predominant commensal microorganism found on human skin (Kloos et al. 1992), was used as a target organism for studies of dissemination and longevity. Using species-specific PCR (Martineau et al. 1996), we were able to detect S. epidermidis in Dry Valley mineral soils collected from sites that are heavily impacted by human activity (Table 1, Fig. 1). The presence of S. epidermidis cells in these high impact areas presumably results from the continuous dissemination of human skin and hair particles. In contrast, $S$. epidermidis could not be detected from mineral soils collected from low impact and 'pristine' sites (Table 1, Fig. 1). The sensitivity of the S. epidermidis-specific primers (Martineau et al. 1996) was tested on DNA extracted from Antarctic volcanic ash seeded with serially diluted S. epidermidis cells (ranging from $1 \times 10^{7} \mathrm{cfu} / \mathrm{g}$ to $1 \times 10^{2} \mathrm{cfu} / \mathrm{g}$ ). The level of detection of S. epidermidis in Antarctic soil was determined to be $1 \times 10^{5} \mathrm{cfu} / \mathrm{g}$ (data not shown). This would imply that either $S$. epidermidis is not present in the lo-impact areas (e.g., pristine sites); or that S. epidermidis is not present in the low-impact areas in numbers below detection levels.

It should be noted that $S$. epidermidis contamination in Antarctic mineral soils has been documented as early as 1978 (Friedmann 1993). It is therefore important to quantify the period that non-indigenous species such as $S$. epidermidis survive in the harsh Antarctic conditions. To address this issue, we inoculated $0.5 \mathrm{~g}$ aliquots of pristine Antarctic soil (BIC4) with $1 \times 10^{5} \mathrm{cfu} / \mathrm{ml}$ S. epidermidis and incubated at $4^{\circ} \mathrm{C}$ for an extended period. At various time intervals, aliquots of seeded soil were serially diluted in Ringer's solution (Merck), plated on Nutrient agar (NA) media (in duplicate) and incubated at $37^{\circ} \mathrm{C}$ for at least $24 \mathrm{~h}$. The colony forming units per millilitre $(\mathrm{cfu} / \mathrm{ml})$ were calculated and plotted against time. Single colonies were 
randomly selected from the NA plates and tested using S. epidermidis-specific PCR (Martineau et al. 1996) primers. S. epidermidis could be isolated from the seeded soil for no more than seven weeks from the time of inoculation (Fig. 2a), with an estimated $t_{50}$ of approximately 4 days. However, S. epidermidis-specific PCR of DNA extracted from these seeded soil samples continued to show a positive amplification signal after 54 weeks (Fig. 2b). Whether this result indicates that $S$. epidermidis continues to exist in a viable but nonculturable (VBNC) state, as non-viable but non degraded cells, or merely as exposed DNA from lysed cells is not clear.

To investigate DNA stability, we seeded $0.5 \mathrm{~g}$ aliquots of BIC4 soil with $\sim 0.3 \mathrm{ng} S$. epidermidis genomic DNA (equivalent to $1 \times 10^{5} \mathrm{cfu} / \mathrm{ml}$ ) and incubated at $4^{\circ} \mathrm{C}$. At various time intervals, bulk DNA was extracted (Stach et al. 2001) from aliquots and used as template DNA in S. epidermidis-specific PCR reactions (Marti-neau et al. 1996). S. epidermidis DNA could be detected in soil DNA extracts (Fig. 3) at the termination of the experiment (23.5 weeks). Although we cannot rule out the possibility that $S$. epidermidis survives in a VBNC state, this result suggests that naked genomic DNA is well preserved in Antarctic soil, possibly due to the low temperatures and water activities typical of Dry Valley soils (Wynn-Williams 1990).

The survival of $S$. epidermidis genomic DNA in these harsh conditions has significant implications for the survival of any other contaminating microorganisms, including those less benign than S. epidermidis (Vincent 2000). Regardless of whether S. epidermidis survives in the VBNC state or purely as naked DNA, these results suggest that in the desiccated mineral soils of the Antarctic continent, incident microbial cells of any source are probably not subject to the rapid lysis and degradation, as is assumed to occur in more temperate and moist environments. Our findings therefore potentially impact both on the interpretation of microbial diversity studies and on the results of gene mining in these 'so called' pristine sites.

Acknowledgements This work was supported by the National Research Foundation HBU RDP program, Antarctica NZ and the University of Waikato Antarctic Terrestrial Biology Program. We thank J.J Smith and J Truter for critical reading of the manuscript.

\section{References}

Baker GC, Ah Tow L, Cowan DA (2003) PCR-based detection of non-indigenous microorganisms in 'pristine' environments. J Microbiol Meth 53:157-164

Bruni V, Maugeri TL, Monticelli L (1997) Faecal pollution indicators in the Terra Nova Bay (Ross Sea, Antarctica). Mar Pollut Bull 34:908-912

Cano RJ, Borucki MK (1995) Revival and identification of bacterial spores in 25- to 40-million-year-old Dominican amber. Science 268:1060-1064

Carpenter EJ, Lin S, Capone DG (2000) Bacterial activity in South pole snow. Appl Environ Microbiol 66:4514-4517

Cowan DA, Ah Tow L (2004) Endangered antarctic environments. Ann Rev Microbiol 58:649-690

Eckford R, Cook FD, Saul D, Aislabie J, Foght J (2002) Free-living heterotrophic nitrogen-fixing bacteria isolated from fuel-contaminated Antarctic soils. Appl Environ Microbiol 68:5181-5185 
Edwards DD, McFeters GA, Venkatesan MI (1998) Distribution of Clostridium perfringens and fecal sterols in a benthic coastal marine environment influenced by the sewage outfall from McMurdo station, Antarctica. Appl Environ Microbiol 64:2596-2600

Friedmann EI (1993) Antarctic Microbiology. Wiley-Liss Inc, New York

Glockner FO, Zaichikov E, Belkova N, Denissova L, Pernthaler J, Pernthaler A, Amann R (2000) Comparative 16S rRNA analysis of lake bacterioplankton reveals globally distributed phy-logenetic clusters including an abundant group of Actinobacteria. Appl Environ Microbiol 66:5053-5065

Gordon DA, Priscu J, Giovannoni S (2000) Origin and phylogeny of microbes living in permanent Antarctic lake ice. Microb Ecol 39: 197-202

Kloos WE, Schleifer K, Gotz F (ed) (1992) The genus Staphylo-coccus: The Prokaryotes 2nd edn. Springer, Berlin Heidelberg New York

Lambert DM, Ritchie PA, Millar CD, Holland B, Drummond AJ, Baroni C (2002) Rates of evolution in ancient DNA from Adelie penguins. Science 295:2270-2273

Martineau F, Picard FJ, Roy PH, Ouellette M, Bergeron MG (1996) Species-specific and ubiquitous DNA-based assays for rapid identification of Staphylococcus epidermidis. J Clin Microbiol 34: 2888-2893

McFeters GA, Barry JP, Howington JP (1993) Distribution of enteric bacteria in Antarctic seawater surrounding a sewage outfall. Water Res 27: 645-650

Priscu JC, Adams EE, Lyons WB, Voytek MA, Mogk DW, Brown RL, McKay CP, Takacs CD, Welch KA, Wolf CF, Kirshtein JD, Avci R (1999) Geomicrobiology of subglacial ice above Lake Vostok, Antarctica. Science 286:2141-2144

Sjoling S, Cowan DA (2000) Detecting human bacterial contamination in Antarctic soils. Polar Biol 23:644-650

Stach JEM, Bathe S, Clapp JP, Burns RG (2001) PCR-SSCP comparison of 16S rDNA sequence diversity in soil DNA obtained using different isolation and purification methods. FEMS Microbiol Ecol 36:139-151

Stokstad E (2003) Paleontology: ancient DNA pulled from soil. Science 300:407

Vincent WF (1988) Microbial ecosystems of Antarctica. Cambridge University Press, Cambridge

Vincent WF (2000) Evolutionary origins of Antarctic microbiota: invasion, selection and endemism. Antarctic Science $12: 374-385$

Weinbauer MG, Beckmann C, Hofle MG (1998) Utility of green fluorescent nucleic acid dyes and aluminium oxide membrane filters for rapid epifluorescence enumeration of soil and sediment bacteria. Appl Environ Microbiol 64:50005003

Willerslev E, Hansen AJ, Binladen J, Brand TB, Gilbert MT, Shapiro B, Bunce M, Wiuf C, Gilichinsky DA, Cooper A (2003) Diverse plant and animal genetic records from Holocene and Pleistocene sediments. Science 300:791-795

Wynn-Williams DD (1990) Ecological aspects of Antarctic microbiology: Advances in Microbial Ecology. Plenum Publishing Corporation, New York 